\title{
ATTITUDES OF STUDENTS AND PARENTS TOWARDS ICT WITH REGARD TO THE EXPERIENCE OF USING THE IPAD IN CLASSROOM
}

\author{
Barbara Rončević Zubković \\ roncevic@ffri.hr \\ Svjetlana Kolić-Vehovec \\ skolic@ffri.hr \\ Barbara Kalebić Maglica \\ bkalebic@ffri.hr \\ Sanja Smojver-Ažić \\ smojver@ffri.hr \\ Rosanda Pahljina-Reinić \\ rosanda@ffri.hr \\ Department of Psychology, \\ Faculty of Humanities and Social Sciences, University of Rijeka, \\ Sveučilišna avenija 4, 51000 Rijeka
}

\begin{abstract}
The interactive information and communication technologies (ICT) have been introduced to many classrooms lately. Therefore, it is important to examine whether the expectations of students and their parents regarding technology implementation are fulfilled. The aim of the present study was to compare attitudes towards ICT in general towards the use of tablet computers in education, regarding the decision to use iPad and the experience of using iPad in the classroom. An attitudes questionnaire was administred in four groups of students and their parents. In the $5^{\text {th }}$ grade, one group has just decided to use iPad in classroom, and one group decided not to use it. In the $7^{\text {th }}$ and $8^{\text {th }}$ grade one group has had two years of experience in using iPad in classroom, while the other group had no experience. The results showed that students and parents who chose to use iPad had more positive attitudes towards tablet use in teaching and learning, and perceived less negative effects of ICT use than students and parents who have not been using iPad. However, a difference between parents' attitudes was found in the $5^{\text {th }}$ grade, but not in the $7^{\text {th }}$ and $8^{\text {th }}$ grades. The parents of older students who
\end{abstract}

Acknowledgement: This study was conducted as a part of the project "Psychological aspects of use of Information and Communication Technologies (ICT) in elementary education" that has been supported by University of Rijeka 
have been using iPad for several years have less positive attitudes towards tablet use than parents of the $5^{\text {th }}$ grade students who just decided to use it. Our findings point to a complex interplay between social norms and experience in educational settings that could be explained within several theoretical frameworks relating to technology acceptance (e.g. TAM2, Venkatesh \& Davis, 2000).

Keywords: attitudes, ICT, tablet computer, elementary school, students, parents

\section{INTRODUCTION}

Educational changes are focused on implementing different interactive technologies with the aim of engaging students in active learning. Among different interactive technologies, handheld devices such as tablet computers, and specifically the iPad, have many benefits as educational tools as they are intuitive to use and have a wide variety of easily downloadable applications (Dhir, Gahwaji, \& Nyman, 2013).

Although the intention of tablet use in education is to promote active learning, the learning experience is not totally dependent upon the device itself, but also on teaching practices and attitudes of teachers, students, and their parents towards the use of information and communication technology (ICT) for educational purposes. Many studies are relatively consistent in the finding that attitudinal factors explain either intention or actual use of ICT in education. For example, effects of teachers' attitudes on the usage of technology-supported teaching were found (Hu, Clark, \& Ma, 2003), as well as the effects of students' attitudes on intention to use tablet devices (Courtois et al., 2014).

Those findings are in line with the Theory of Reasoned Action (Ajzen \& Fishbein, 2005; TRA) that envisions behavior as a function of behavioral intention, which is in turn based upon attitudes and subjective norms. Attitude refers to positive or negative affective responses towards performing certain behaviour, but it also contains the beliefs held towards behavioral outcomes, and the extent to which these are valued. Subjective norms comprise perceptions of how significant others feel about the actor's behaviour. In information systems research, TRA has been adapted to what is called the Technology Acceptance Model (TAM), which was initially composed by explanatory elements such as perceived ease of use and perceived usefulness (Davis, Bagozzi, \& Warshaw, 1989), and later on supplemented - among other constructs - by subjective norm and experience with technology system. Experience could weaken the effect of subjective norms on perceived usefulness (TAM2, Venkatesh \& Davis, 2000)

Most of the studies examining attitudes towards ICT implementation in education focus on teachers. Hence, in this study we explicitly focus on students' and their parents' attitudes towards ICT. Studies have shown that students generally have positive attitudes (European Commission, 2013) and high expectations (Courtois et al., 2014) towards the implementation of ICT in education. Most students believe that using ICT during lessons has a positive effect on class atmosphere and various deep 
learning processes (European Commission, 2013). Similarly, students perceive iPad as a helpful learning tool that they enjoy using (Goodwin, 2012). Jennings, Anderson, Dorset, and Mitchell (2011) found that $80 \%$ of students have strongly favoured the use of iPad in the classroom.

Parental attitudes towards the use of ICT in schools have been explored to a les ser extent. Some studies conducted in the USA (Hart Research Associates Poll, 2012) showed that both parents and teachers believe it is important for schools to make good use of technology in educating students. Most of the parents are also aware of potential negative effects of electronic media on their children (e.g. Pregrad, Tomić Latinac, Mikulić, \& Šeparović, 2011). According to TRA, it could be hypothesized that technology acceptance in students is related to the attitudes towards ICT in their parents., The subjective norm of students in the educational context reflects the attitudes of their parents, especially in younger children, while peers, in general, became more influential as adolescents become older (e.g., Duncan, Duncan, \& Hops, 1994). However, direct experience with technology could diminish the impact of social cues on intention to use ICT (Venkatesh \& Davis, 2000).

The purpose of the present study was to compare attitudes towards ICT in general and towards use of tablet computers in education regarding decision to use and experience in the use of iPad in classroom. More specifically, the aim was to compare attitudes of students and parents who have just decided to use or not to use iPad in classroom in the $5^{\text {th }}$ grade, with attitudes of higher-elementary $\left(7^{\text {th }}\right.$ and $\left.8^{\text {th }}\right)$ grade students and their parents who have had or have not had experience in iPad use.

It can be hypothesized that students who are going to use, or already use iPad in classrooms, as well as their parents, would have more positive attitudes towards ICT in general, and towards tablets use in education, and that they will perceive ICT as more important than students and parents who do not use the iPad, since people are prone to rate the selected choice as better, and the rejected option as worse (Brehm, 1956).

Since there is a scarcity of studies that examined long-term effects of ICT uptake in education by students and their parents, we could only assume that longer experience in iPad use could have positive effects on students' and parents' attitudes as they realize its possibilities and become more proficient users. That assumption would be in line with the TAM that postulates that acceptance of ICT is related to perceived usefulness and ease of use (Davis et al., 1989).

\section{METHOD}

\section{Participants}

In this study 109 students (54.8\% female, $10-14$ years of age) and 90 parents ( $81 \%$ female, mean age 41.64 ) from one elementary school in Rijeka, Croatia, par- 
ticipated in the study. At the beginning of the $5^{\text {th }}$ grade, students and their parents are given the opportunity to decide if they want to use the iPad device in every school subject, at their own expense. In the fifth grade 22 students decided to use the iPad and 21 decided not to. In the $7^{\text {th }}$ and $8^{\text {th }}$ grade 33 students have been using the iPad for two years and 33 students don't use the iPad in classrooms.

\section{Instruments}

The questionnaire was constructed for the purpose of a larger project. Answers on all items were scored on a 4 point scale (from 1-completely disagree to 4-completely agree). Demographic data (age, gender, iPad use in the classroom, grade) were also collected. A term tablet instead of $i$ Pad was used in all the scales, in order to be applicable in different schools from the larger project.

All participants assessed their attitudes towards ICT (table, laptop and tablet computers, smartphones, Internet) on a 20-item scale. Exploratory factor analysis was conducted and results indicated a two factor solution. Positive aspects of ICT mainly reflected usefulness of ICT and Negative aspects of ICT mainly reflected negative consequences of ICT use. Reliability coefficients (Cronbach alpha) in the sample of students and their parents ranged from .79 to .84 .

A twelve-item scale was used to assess students' opinion about the use of tablet in teaching and learning. Exploratory factor analysis showed one factor solution reflecting positive attitude towards tablet use and perception of usefulness of tablets in classrooms settings. The items relating to undesirable aspects were omitted in order to keep internal consistency. Reliability coefficient (Cronbach alpha) of nineitem scale for students was .93 and for parents .92 .

Students' self-efficacy and importance of computer and tablet use was assessed with eight items. Exploratory factor analysis showed one factor solution with satisfactory internal consistency (Cronbach alpha was .83).

Parents assessed the importance of computer and tablet use for their children on a four-item scale (Cronbach alpha was .78).

\section{Procedure}

Questionnaires for students were group administrated during regular classes in the first week of school, after parents gave informed consent for their own and their child's participation in the study. Group administration of parents' questionnaires in the school took approximately 20 minutes. Although the study was not anonymous, confidentiality was guaranteed to participants. 


\section{RESULTS AND DISCUSSION}

In order to examine the effects of grade and iPad use on students' attitudes towards ICT and tablet use, and self-efficacy and importance of ICT, a series of two-way ANOVAs (Grade $\times$ iPad Use) was performed. The results are shown in Table 1.

As shown in Table 1. students perceive similar, moderate levels of both positive and negative aspects of ICT, that could reflect ambivalent attitudes toward ICT (Conner \& Armitage, 2008). Scales assessing positive and negative aspects of ICT are only moderately related (-.38). These results are in line with previous findings that suggest that both children and adults can think that ICT is useful, but at the same time considered it to be dangerous (Pregrad et al., 2011).

As expected, students who are going to use, or already use iPad in learning, perceive more positive aspects of ICT and have more positive attitudes toward tablet use in teaching and learning compared to students who do not use iPad in classroom. They also think that ICT is important and see themselves as more competent in ICT use compared to students who do not use iPad in classroom. It is possible that focusing on more positive aspects of ICT among iPad users could reflect their attempt to justify their decision (Brehm, 1956) but also it can be related to years of experience with ICT (TAM2, Venkatesh \& Davis, 2000).

However, an interaction was found suggesting that the $5^{\text {th }}$ grade students who are going to use iPad show higher self-efficacy in ICT use then students who de-

Table 1. Average Values and the Results of Two-Way ANOVAs (Grade $\times$ iPad Use) for Students' Attitudes

\begin{tabular}{|c|c|c|c|c|c|c|c|c|c|}
\hline & & \multicolumn{2}{|c|}{$5^{\text {th }}$ grade } & \multicolumn{2}{|c|}{$7^{\text {th }} \& 8^{\text {th }}$ grade } & \multirow[b]{2}{*}{ 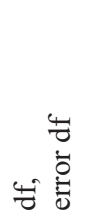 } & \multirow[b]{2}{*}{ 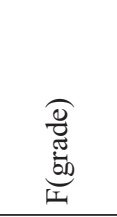 } & \multirow[b]{2}{*}{ 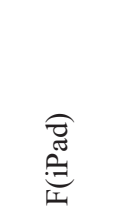 } & \multirow{2}{*}{ 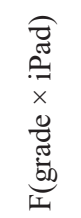 } \\
\hline & & 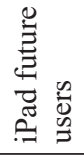 & 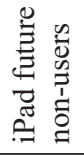 & 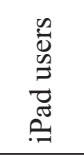 & 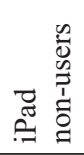 & & & & \\
\hline $\begin{array}{l}\text { Positive aspects } \\
\text { of ICT }\end{array}$ & $\begin{array}{l}M \\
S D\end{array}$ & $\begin{array}{l}2.71 \\
0.52\end{array}$ & $\begin{array}{l}2.46 \\
0.38\end{array}$ & $\begin{array}{l}3.02 \\
0.46\end{array}$ & $\begin{array}{l}2.73 \\
0.43\end{array}$ & 1,98 & $10.26^{* *}$ & $8.71 * *$ & 0.02 \\
\hline $\begin{array}{l}\text { Negative aspects } \\
\text { of ICT }\end{array}$ & $\begin{array}{l}M \\
S D\end{array}$ & $\begin{array}{l}2.74 \\
0.52\end{array}$ & $\begin{array}{l}2.95 \\
0.56\end{array}$ & $\begin{array}{l}2.69 \\
0.73\end{array}$ & $\begin{array}{l}2.80 \\
0.69\end{array}$ & 1,92 & 0.48 & 1.32 & 0.12 \\
\hline $\begin{array}{l}\text { Positive attitudes } \\
\text { towards tablet }\end{array}$ & $\begin{array}{l}M \\
S D\end{array}$ & $\begin{array}{l}3.17 \\
0.35\end{array}$ & $\begin{array}{l}2.06 \\
0.28\end{array}$ & $\begin{array}{l}2.79 \\
0.55\end{array}$ & $\begin{array}{l}2.06 \\
0.70\end{array}$ & 1,91 & 3.04 & $68.19 * *$ & 3.04 \\
\hline $\begin{array}{l}\text { Self-efficacy and } \\
\text { importance of } \\
\text { ICT }\end{array}$ & $\begin{array}{l}M \\
S D\end{array}$ & $\begin{array}{l}3.14 \mathrm{a} \\
0.40\end{array}$ & $\begin{array}{l}2.64 \mathrm{~b} \\
0.64\end{array}$ & $\begin{array}{l}3.04 \\
0.44^{\mathrm{a}}\end{array}$ & $\begin{array}{l}2.98 \\
0.44\end{array}$ & 1,95 & 1.42 & $7.57 * *$ & $4.92 *$ \\
\hline
\end{tabular}

$* p<.05, * * p<.01$. Means within a row with different subscripts differ significantly at the $p<.01$ or $p<.05$ level (Duncan's test). 


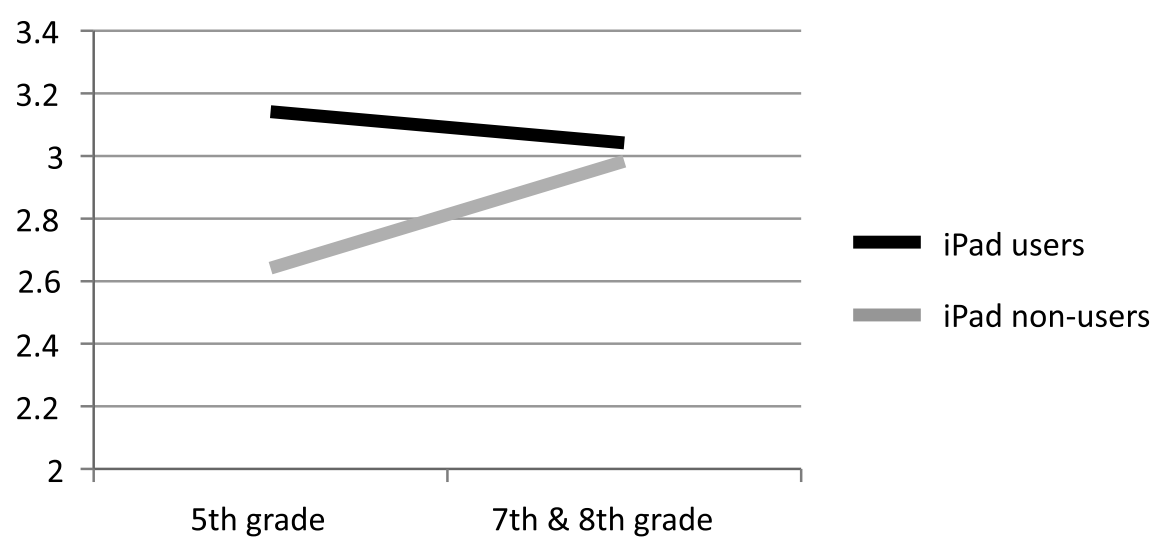

Figure 1. Interaction Effect (Grade $\times$ iPad Use) on Students' Self-efficacy and Importance of Computer and Tablet Use

cided not to use iPad, but there is no such difference between older iPad users and non-users (Figure 1).

It is possible that precisely because they do not see the importance of ICT and/ or consider themselves less competent in ICT use, some $5^{\text {th }}$ grade students and their parents decided not to use iPad in classroom. This would be in line with the TAM model (Davis et al., 1989) that postulates that perceived usefulness and ease of use predict intentions to use technology.

However, the lack of difference in self-efficacy and perceived importance of ICT observed in older iPad users and non-users points to the conclusion that students who do not use the iPad in the classroom acquire enough experience in the use of ICT devices outside school, so they develop competence in ICT use and recognize its importance.

The results also show that older students perceive more positive aspects of ICT compared to $5^{\text {th }}$ graders. This also might be because older students use ICT more frequently and for a wider variety of purposes, especially for social networking and entertainment. This is also in line with the TAM model (Davis et al., 1989) as it points to greater perceived usefulness of ICT in older students.

Although it was expected that iPad users, especially students who have just decided not to use the iPad, will be more inclined to perceive more negative aspects of ICT, this premise was not supported. Since the scale assessing negative aspects of ICT refers mainly to potential threats of using ICT in general, it is possible that both iPad users and non-users are aware of those threats since they all use different ICT devices, but iPad users are more prone to see positive aspects as well.

In order to examine the effects of grade and iPad (intention) use on parents' attitudes towards ICT and tablet use, and perceived importance of ICT, a series of two-way ANOVAs (Grade $\times$ iPad Use) was performed (Table 2). 
Table 2. Average Values and the Results of Two-Way ANOVAs (Grade $\times$ iPad Use) for Parents' Attitudes

\begin{tabular}{|c|c|c|c|c|c|c|c|c|c|}
\hline & & \multicolumn{2}{|c|}{$5^{\text {th }}$ grade } & \multicolumn{2}{|c|}{$7^{\text {th }} \& 8^{\text {th }}$ grade } & \multirow[b]{2}{*}{ 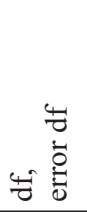 } & \multirow[b]{2}{*}{ 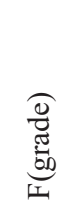 } & \multirow[b]{2}{*}{ 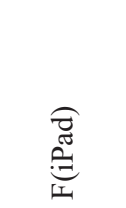 } & \multirow[b]{2}{*}{ 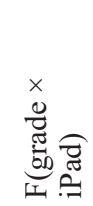 } \\
\hline & & 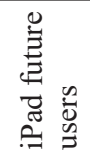 & 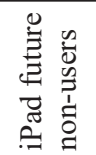 & 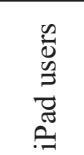 & 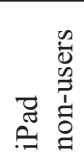 & & & & \\
\hline $\begin{array}{l}\text { Positive aspects } \\
\text { of ICT }\end{array}$ & $\begin{array}{l}M \\
S D\end{array}$ & $\begin{array}{l}2.99 \\
0.31^{a}\end{array}$ & $\begin{array}{l}2.50_{\mathrm{b}} \\
0.30\end{array}$ & $\begin{array}{l}2.36_{\mathrm{b}} \\
0.36^{6}\end{array}$ & $\begin{array}{l}2.63_{\mathrm{b}} \\
0.38^{\mathrm{N}}\end{array}$ & 1,82 & 1.55 & $10.44 * *$ & $8.99 * *$ \\
\hline $\begin{array}{l}\text { Negative aspects } \\
\text { of ICT }\end{array}$ & $\begin{array}{l}M \\
S D\end{array}$ & $\begin{array}{l}2.65 \\
0.53^{\mathrm{a}}\end{array}$ & $\begin{array}{l}3.19 \mathrm{~b} \\
0.33\end{array}$ & $\begin{array}{l}2.97^{b} \\
0.52^{b}\end{array}$ & $\begin{array}{l}3.04^{b} \\
0.53\end{array}$ & 1,86 & 0.57 & $8.24 * *$ & $4.59 *$ \\
\hline $\begin{array}{l}\text { Positive attitudes } \\
\text { towards tablet }\end{array}$ & $\begin{array}{l}M \\
S D\end{array}$ & $\begin{array}{l}2.93 \\
0.54\end{array}$ & $\begin{array}{l}2.22 \\
0.22\end{array}$ & $\begin{array}{l}2.51_{b} \\
0.34\end{array}$ & $\begin{array}{l}2.30_{\mathrm{b}} \\
0.55^{\circ}\end{array}$ & 1,80 & 2.81 & $20.11 * *$ & $6.13^{*}$ \\
\hline $\begin{array}{l}\text { Importance of } \\
\text { ICT }\end{array}$ & $\begin{array}{l}M \\
S D\end{array}$ & $\begin{array}{l}3.29 \\
0.50\end{array}$ & $\begin{array}{l}3.25 \\
0.42\end{array}$ & $\begin{array}{l}3.21 \\
0.43\end{array}$ & $\begin{array}{l}3.23 \\
0.38\end{array}$ & 1,89 & 0.32 & 0.00 & 0.14 \\
\hline
\end{tabular}

${ }^{*} p<.05,{ }^{*} p<.01$. Means within a row with different subscripts differ significantly at the $p<.01$ or $p<.05$ level (Duncan's test).

The results (Table 2) show that there were no differences in attitudes between parents of younger and older students. Furthermore, there was no difference in the parents' perceived importance of ICT depending on their children's age and iPad use. However, a significant main effect of iPad use was found on positive and negative aspects of ICT and on positive attitudes towards tablet use. Interestingly, interaction effects of grade and iPad use were also obtained (Figures 2, 3, and 4).

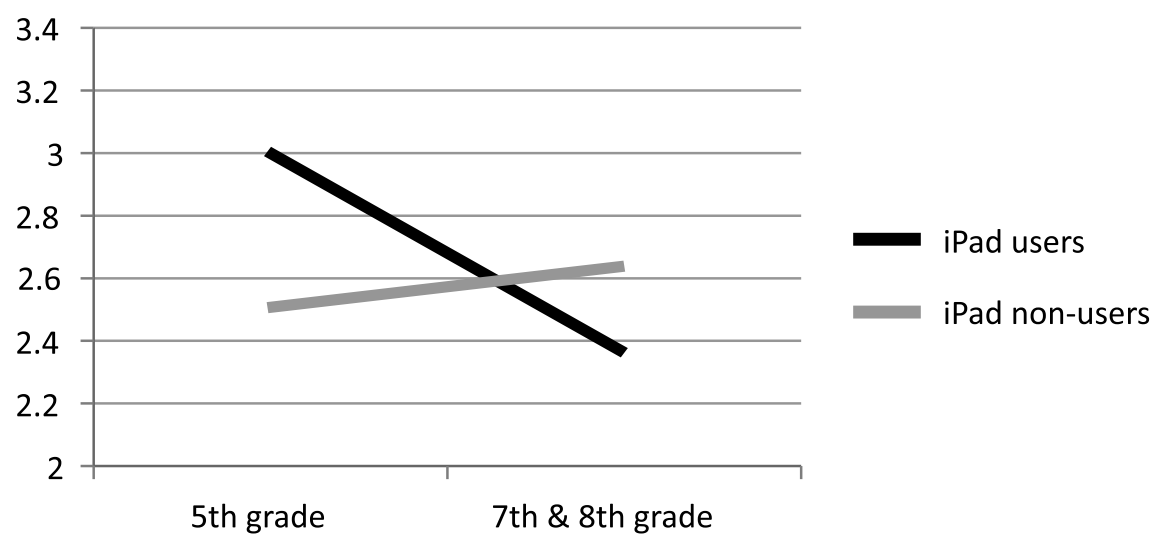

Figure 2. Interaction Effect (Grade $\times$ iPad Use) on Parents' Perception of Positive Aspects of ICT 


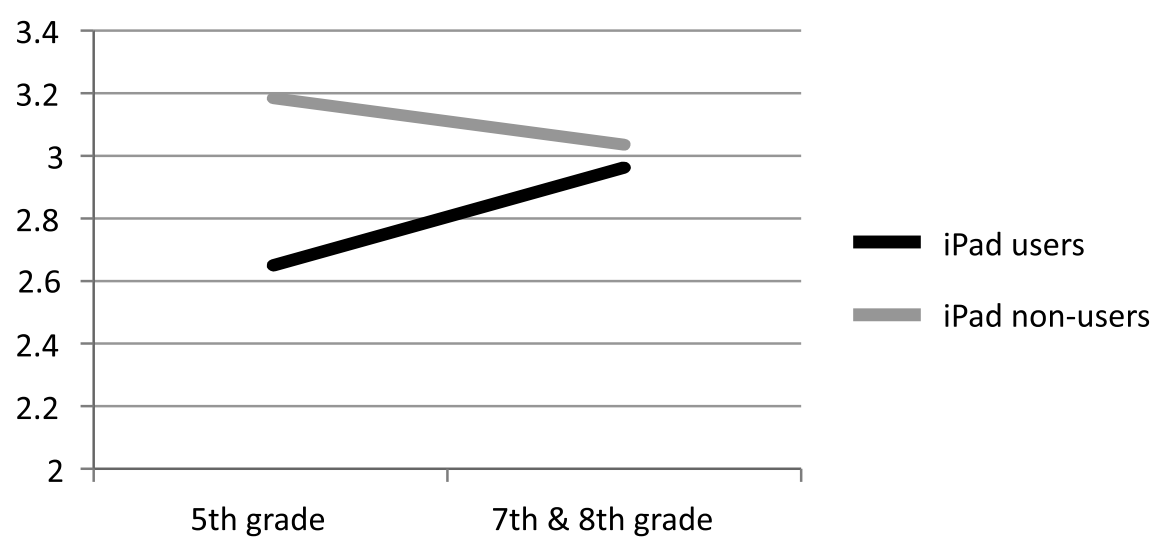

Figure 3. Interaction Effect (Grade $\times$ iPad Use) on Parents' Perception of Negative Aspects of ICT

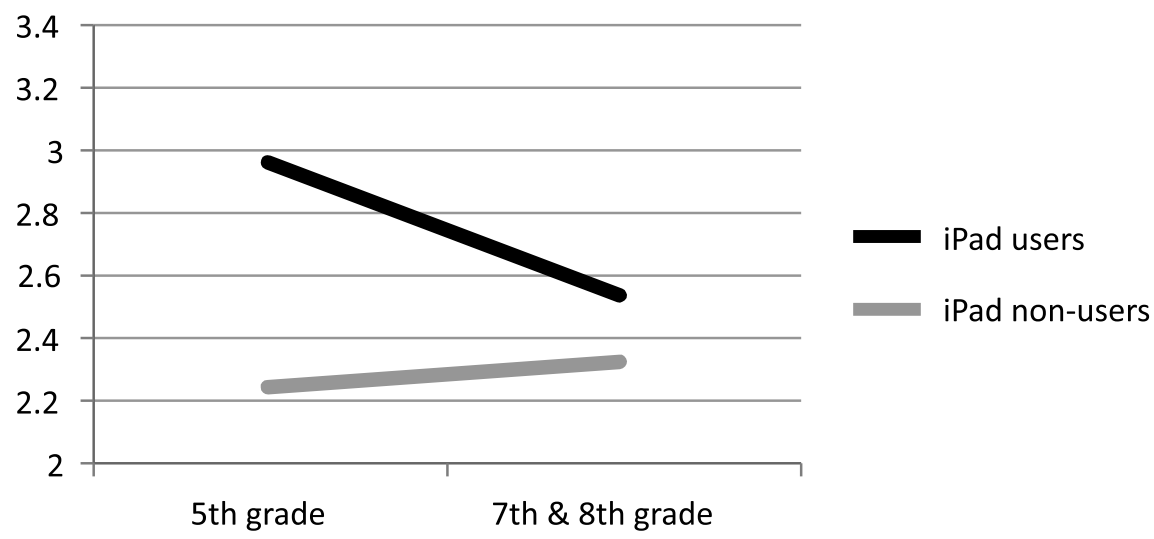

Figure 4. Interaction Effect (Grade $\times$ iPad Use) on Parents' Positive Attitudes Towards Tablet Use in Teaching and Learning

Parents of future iPad users perceive more positive and less negative aspects of ICT and have more positive attitudes towards the use of tablet in learning, probably justifying their choice (Brehm, 1956). However, parents whose children have been using the iPad in classroom for two years did not differ in their attitudes from parents whose children have not been using the iPad. It is possible that parents of future iPad users have high expectations towards tablet use in education. Although some studies show that iPad encouraged teachers to start using innovative teaching approaches that are more student-centered and engaging, handheld devices are still 
mainly used to support traditional curricula (Goodwin, 2012). Therefore it is possible that in the $5^{\text {th }}$ grade parents held (unrealistically) high expectations that are not fully met. With experience, perceptions become more realistic and less susceptible to subjective norms (Venkatesh \& Davis, 2000).

Given these findings, we can agree with the recommendation of Courtois et al. (2014) that when introducing innovative technologies in education, implementation should be gradual, and expectations should be toned down to avoid loss of enthusiasm for ICT in parents. Additionally, sufficient ongoing support should be available to teachers in order to make full use of potential ICT advantages in education.

In order to generalize the obtained findings, additional surveys have to be conducted on larger samples. However, this is one of the rare studies that included the assessment of the long-term effects of attitudes toward ICT. More positive attitudes were observed in students who use iPad in classrooms, as well as in their parents, implying that attitudes are aligned with the decision (Brehm, 1956). However, while after two years of experience in iPad use in classroom iPad users perceived more positive aspects of both ICT and the iPad, compared to their peers (iPad non-users), their parents did not differ in their attitudes from parents whose children have not been using the iPad. In terms of TAM2 model, these results suggest that experience with a particular ICT system provides better insight into its strengths and weaknesses and serve as a basis for usefulness perceptions and intentions toward ongoing use, while reducing the impact of social cues. Thus, the interplay between social norms and experience in educational settings while focusing on long-term effects of ICT implementation should be further elaborated in future research and theories.

\section{REFERENCES}

Ajzen, I., \& Fishbein, M. (2005). The influence of attitudes on behavior. In D. Allbarracin, B.T. Johnson, \& M.P. Zanna (Eds.), Handbook of attitudes (pp. 173-222). London: Lawrence Erlbaum Associates.

Brehm, J.W. (1956). Postdecision changes in the desirability of alternatives. Journal of Abnormal and Social Psychology, 52, 384-9.

Conner, M., \& Armitage, C.J. (2008). Attitudinal ambivalence. In W.D. Crano \& R. Prislin (Eds.), Attitudes and attitude change. Frontiers of social psychology (pp. 261-286). New York: Psychology Press.

Courtois, C., Montrieux, H., De Grove, F., Raes, A., De Marez, L., \& Schellens, T. (2014). Student acceptance of tablet devices in secondary education: A three-wave longitudinal cross-lagged case study. Computers in Human Behavior,35, 278-286.

Davis, F.D., Bagozzi, R.P., \& Warshaw, P.R. (1989). User acceptance of computer technology: A comparison of two theoretical models. Management Science, 35(8), 982-1003.

Dhir, A., Gahwaji, N.M., \& Nyman, G. (2013).The role of the iPad in the hands of the learner. Journal of Universal Computer Science, 19(5), 706-727. 
Duncan, T.E., Duncan, S.C., \& Hops, H. (1994). The effect of family cohesiveness and peer encouragement on the development of adolescent alcohol use: A cohort-sequential approach to the analysis of longitudinal data. Journal of Studies on Alcohol, 55, 588-599.

European Commission (2013). Survey of schools: ICT in education. Luxemburg: Publication Office of European Union. Retrieved from: https:/ec.europa.eu/digital-agenda/ sites/digital-agenda/files/KK-31-13-401-EN-N.pdf

Goodwin, K. (2012). Use of tablet technology in the classroom. State of New South Wales, Department of Education and Communities. NSW Curriculum and Learning Innovation Centre. Retrieved from: http://clic.det.nsw.edu.au/clic/documents/iPad_Evaluation_Sydney_Region_exec_sum.pdf

Hart Research Associates Poll (2012). Parents' and teachers' attitudes and opinions on technology in education. LEAD Commision. Retrieved from: http://www.leadcommission. org/sites/default/files/LEAD\%20Poll\%20Deck.pdf

Hu, P.J.H., Clark, T.H.K., \& Ma, W.W. (2003). Examining technology acceptance by school teachers: A longitudinal study. Information \& Management, 41(2), 227-241.

Jennings, G., Anderson, T., Dorset, M., \& Mitchell, J. (2011). Report on the Step forward $i$ Pad pilot project. Trinity College, The University of Melbourne. Retrieved from http:// www.trinity.unimelb.edu.au/Media/docs/iPadPilotReport2011-1b1e1a52-79af-4c76b5b6-e45f92f2c9e9-0.pdf.

Pregrad, J., Tomić Latinac, M., Mikulić, M., \& Šeparović, N. (2011). Iskustva i stavovi djece, roditelja i učitelja prema elektroničkim medijima. Ured UNICEF-a za Hrvatsku. Retrieved from: http://www.unicef.hr/upload/file/353/176706/FILENAME/Izvjestaj_-_Iskustva_i_stavovi_djece_roditelja_i_ucitelja_prema_elektronickim_medijima.pdf

Venkatesh, V., \& Davis, F. D. (2000). A theoretical extension of the technology acceptance model: Four longitudinal field studies. Management Science, 46(2), 186-204.

\title{
STAVOVI UČENIKA I RODITELJA PREMA IKT-U S OBZIROM NA ISKUSTVO KORIŠTENJA IPAD RAČUNALA U NASTAVI
}

\begin{abstract}
Sažetak
Interaktivne informacijsko-komunikacijske tehnologije (IKT) u novije vrijeme uvode se u sve veći broj škola. Stoga je važno ispitati očekivanja učenika i njihovih roditelja vezano za uvođenje navedene tehnologije. Cilj je ovoga istraživanja bio usporediti stavove prema IKT-u općenito i stavove prema upotrebi tablet računala u obrazovanju s obzirom na odluku o korištenju iPad-a i iskustvo u njegovom korištenju $\mathrm{u}$ razredu. S tim ciljem upitnik stavova primijenjen je u četiri skupine učenika i njihovih roditelja. U petom razredu jedna skupina je upravo odlučila da će koristiti iPad u nastavi, dok je druga odlučila da neće. U sedmom i osmom razredu jedna skupina
\end{abstract}


učenika ima dvogodišnje iskustvo korištenja iPada u nastavi, dok druga skupina nema takvo iskustvo. Rezultati su pokazali da učenici i roditelji koji su odabrali koristiti iPad imaju pozitivnije stavove prema korištenju tableta u poučavanju i učenju te percipiraju manje negativnih efekata korištenja IKT-a, za razliku od učenika i roditelja koji se nisu odlučili za korištenje iPad-a. Međutim, pronađena je razlika u roditeljskim stavovima u petom razredu, ali ne i u sedmom i osmom razredu. Roditelji starijih učenika koji iPad koriste već nekoliko godina imaju manje pozitivne stavove prema korištenju tableta, u odnosu na roditelje u petom razredu koji su se upravo odlučili za korištenje iPad-a. Nalazi ovog istraživanja sugeriraju na kompleksno uzajamno djelovanje socijalnih normi i iskustva u obrazovnim okruženjima, koje se može objasniti u okviru više teorijskih modela koji se odnose na prihvaćanje tehnologije (npr. TAM2, Venkatesh \& Davis, 2000).

Ključne riječi: stavovi, IKT, tablet računalo, osnovna škola, učenici, roditelji

Prihvaćeno za tisak: 07. 09. 2016. 
